\title{
Preparing Preservice Teachers for Technology and Digital Media Integration: Implications for Early Childhood Teacher Education Programs
}

\author{
Ali M. Alelaimat ${ }^{1} \cdot$ Fathi M. Ihmeideh ${ }^{1}$ (D) Mustafa F. Alkhawaldeh ${ }^{1}$
}

Accepted: 24 November 2020 / Published online: 17 January 2021

(C) The Author(s), under exclusive licence to Springer Nature B.V. part of Springer Nature 2021

\begin{abstract}
Technology and digital media are now embedded in children's daily lives and can have significant impact on children's early development and learning. Preparing early childhood teachers to integrate a variety of technologies into classroom practices can be challenging. This study explores perceptions of preservice teachers about technology integration into their educational programs and assesses their satisfaction with such preparation. A total of 192 preservice teachers participated in this study. Data were collected through questionnaires and in-depth interviews. Results indicated that preservice teachers held positive perceptions of the importance of technology and digital media integration in early childhood classrooms. However, their satisfaction with their preparation for technology integration into classrooms was less positive. Knowledge needs indicated by the preservice included learning more about technology integration in practice, and how to engage children in activities using technology and digital media. Based on the overall findings, it seems that teacher education programs need to develop stronger curricula that address these concerns so that future teachers are more confident and able to support children's learning through integration of technologies into their teaching practice.
\end{abstract}

Keywords Technology integration - Digital media $\cdot$ Teacher education programs . Preservice teachers $\cdot$ Early childhood education

\section{Résumé}

La technologie et les médias numériques sont désormais intégrés dans la vie quotidienne des enfants et peuvent avoir un impact significatif sur le développement et l'apprentissage des jeunes enfants. Préparer les enseignants de la petite enfance à intégrer diverses technologies aux pratiques de la classe peut constituer un défi. Cette étude explore les perceptions des enseignants en formation initiale sur l'intégration

Fathi M. Ihmeideh

fathiihmeideh@hotmail.com

1 Department of Child Education, Queen Rania Faculty for Childhood, The Hashemite University, P.O. box 330127, Zarqa 13133, Jordan 
des technologies dans leurs programmes éducatifs et évalue leur satisfaction par rapport à une telle préparation. Un total de 192 enseignants en formation initiale a participé à cette étude. Des questionnaires et des entretiens approfondis ont servi à recueillir les données. Les résultats indiquent que les enseignants en formation initiale perçoivent de façon positive l'importance de l'intégration des technologies et des médias numériques dans les classes de la petite enfance. Leur satisfaction est toutefois moins positive pour ce qui est de leur préparation à cette intégration de la technologie dans les classes. Les enseignants en formation initiale expriment le besoin de plus de connaissances relatives à la façon d'intégrer la technologie dans la pratique et d'engager les enfants dans des activités utilisant la technologie et les médias numériques. D'après les résultats généraux, il semble que les programmes de formation des enseignants devraient élaborer des curriculums plus solides pour répondre à ces préoccupations afin que les futurs enseignants se sentent plus en confiance et à même d'accompagner l'apprentissage des enfants par l'intégration de technologies dans leur pratique d'enseignement.

\section{Resumen}

La tecnología y los medios digitales están ahora integrados en la vida diaria de los niños y pueden tener un impacto significativo en el desarrollo y el aprendizaje temprano de los niños. Preparar a los maestros de la primera infancia para que integren una variedad de tecnologías en las prácticas del aula puede ser un desafío. Este estudio explora las percepciones de los futuros profesores sobre la integración de la tecnología en sus programas educativos y evalúa su satisfacción con dicha preparación. Un total de 192 profesores en formación participaron en este estudio. Los datos se recopilaron mediante cuestionarios y entrevistas en profundidad. Los resultados indicaron que los maestros en formación tenían una percepción positiva de la importancia de la tecnología y la integración de los medios digitales en las aulas de la primera infancia. Sin embargo, su satisfacción con su preparación para la integración de la tecnología en las aulas fue menos positiva. Las necesidades de conocimiento indicadas por los futuros maestros incluyeron aprender más sobre la integración de la tecnología en la práctica y cómo involucrar a los niños en actividades utilizando tecnología y medios digitales. Sobre la base de los hallazgos generales, parece que los programas de formación docente deben desarrollar planes de estudio más sólidos que aborden estas preocupaciones para que los futuros maestros tengan más confianza y puedan apoyar el aprendizaje de los niños mediante la integración de tecnologías en su práctica docente.

\section{Introduction}

Technology and digital media have become an integral part of children's daily lives, even in early childhood (Donohue 2015; Smahelova et al. 2017). Technology and digital media refer to tools that are used in teaching and learning in the digital age, including, but are not limited to, personal computers, laptops, tablets, and smartphones with internet connection, televisions, digital games, interactive websites, 
and a range of other devices (Donohue 2015). Research indicates that these tools can promote children's development and learning when used effectively and appropriately in early childhood settings (Ihmeideh 2014; Ihmeideh and Al-Khawaldeh 2017; Palaiologou 2016). Given the importance of providing children with multiple opportunities to learn through technology, it is essential that teacher education programs provide preservice teachers with the knowledge and skills for effective use of technology and digital media in classrooms (Dong and Mertala 2019).

In the context of Jordanian early childhood education and our involvement in teacher education programs, we noticed that beginning teachers often started classroom teaching with inadequate technological knowledge and skills. New graduates of teacher education programs, employed in kindergartens, rarely integrated technology and digital media into teaching practices. In addition, preservice teachers started fieldwork during their course with little or no knowledge of technology integration. This view has been supported by research that indicates that beginning teachers do not take advantage of the potential use of technology in providing educational support to students (Hu and McGrath 2011).

In Jordan, there is a lack of research on preservice teachers' knowledge about technology integration or the extent to which teachers are satisfied with the technological skills and knowledge that is available to them in teacher education programs. This study explores how teacher education programs prepare teachers for technology integration in early childhood classrooms and also investigates the knowledge needs that preservice teachers ${ }^{1}$ have with respect to technology integration.

\section{Preparing Teachers for Technology Integration}

Researchers in educational technology have identified a number of methods to help preservice teachers develop technological skills so that they could integrate these skills into their teaching practice (Tondeur et al. 2012), including providing teachers with practical technology-related courses. Most early childhood teacher education programs include courses related to educational technology, digital media, information and communication technology, and/or computers. Research studies also have identified that teachers who displayed strong and positive attitudes toward technology integration are more likely to then put their skills into practice (Gulbahar 2008; Nikolopoulou and Gialamas 2009; Tezci 2011). For example, Gulbahar (2008) examined prospective teachers' experiences of technology integration and found positive correlations between teachers' experiences with computers, their attitudes toward computer, and their confidence in using computers in classrooms.

Nikolopoulou and Gialamas (2009) found that preservice early childhood teachers expressed positive views about integration and use of computers in early childhood settings in Greece. In another study, Tondeur et al. (2017) examined beginning

\footnotetext{
${ }^{1}$ Note Preservice teachers in this present study refer to trainee teachers who are completing their initial training for early childhood education. The terms 'student teachers' and 'preservice teachers' are used interchangeably.
} 
teachers' use and integration of technology and found that beginning teachers could use technology in student-centered ways. Fieldwork experiences were the main factor that affected how teachers could use technology in subsequent classroom practice. While Tezci (2011) reporting on a Turkish study found that teachers primarily used only basic applications, such as word-processing programs and presentation software. These preservice teachers indicated that their knowledge of advanced technological applications, such as modeling software, was lacking. It is essential for new teachers entering the profession to have adequate technological knowledge and skills and be able to use these skills effectively in their classrooms and continue to advance their competence. In many cases, however, the technology available in educational systems is not sufficient to improve and advance teaching and provide learning support to students in classrooms (Tezci 2011).

In Australia, Yelland et al. (2006) explored how early childhood professionals were prepared to use and interact with technology in classrooms. They found that both undergraduate and graduate students had little knowledge about, or skills in technology usage, before embarking on technology-related courses. Participation in technology courses had helped them to acquire new knowledge and skills and use it in educational practice. Mueller et al. (2008) explored teachers' views, beliefs and attitudes as a step toward developing effective professional development programs, although less attention has been directed to this issue in teacher education programs.

\section{Research Context}

The present study was conducted in Jordan at the Hashemite University, which is a public university. It was established in 1995 and is located in Zarqa city, the second and largest city in Jordan. It has 13 colleges, including Queen Rania Faculty for Childhood (QRFC), which is responsible for teacher qualifications in early childhood education to teach children aged from 3 to 6 years. QRFC has two departments: Department of Child Education and the Department of Special Education. The Department of Child Education offers a bachelor's degree in early childhood education.

The early childhood teacher education program provides preservice teachers with 132 credit hours in courses designed to give them opportunities to provide education for young children and to prepare instructional materials and curricula for children (The Hashemite University 2002). Such courses include: Using Computer in Teaching Children, Design Materials for Children, and Contemporary Issues in Early Childhood. These courses are intended to provide students with the skills to integrate technology into teaching practices, while other courses allow students to interact with technology through assignments, presentations, and exams. Many courses offered in this department require students to use Moodle, an online learning platform designed to provide teaching staff and learners with an integrated online management system. In addition, the department offers two courses that are completely delivered online. According to the study plan for the overall course, when students have successfully passed 114 from 132 credit hours of their study successfully, they are ready to start an internship course (6 credit hours) in kindergartens, in 
which they are required to integrate technology into their teaching practices (Ihmeideh et al. 2008).

\section{The Current Study}

This study will provide research-based evidence about the quality of technology integration in early childhood education teacher education programs to fill a gap in existing research. The study explores how teacher education prepares students for technology integration in early childhood classrooms and investigates their knowledge needs with respect to technology integration. This study is timely because during the COVID-19 pandemic in 2020, technology as digital platforms can provide important opportunities for teachers to support young children's learning at home. This global pandemic has highlighted the importance of preparing teachers to have the skills to use a variety technological software in order to design learning activities that can support children's learning, at home and in classrooms.

In this research, information on two demographic variables is also considered. Seniority in study at university and grade point average (GPA) were also included in the analyses to identify variability and differences in preservice teachers' perceptions about technology integration. We assumed that student teachers' views might vary based on seniority (freshman, sophomore, junior, and senior), as more senior preservice teachers would have had more exposure and experience in technology integration, as well as participation in the fieldwork program. As a result, senior students might hold stronger beliefs about technology integration than freshman, sophomore, or junior students. Tondeur et al. (2017) pointed out that preservice teachers' fieldwork experiences were the most significant factor influencing their beliefs and teaching practices with technology. Other studies have also found that senior university students had more positive attitudes toward learning through computer-assisted instruction than freshman, sophomore, and junior counterparts (Akbulut 2008; Mahfouz and Ihmeideh 2009). In addition, we expected that student teachers with higher GPAs would be more likely to hold more positive views and have a greater interest in technology integration, because they were more likely to have earned higher marks in technology-related courses. Tang and Austin (2009) found that university students with higher GPAs also tended to favor the effective use of technology.

The research questions that framed this research were:

1. What are preservice teachers' perceptions on the importance of technology and digital media in early childhood education?

2. To what extent are preservice teachers satisfied with their preparation for integrating technology and digital media into teaching practice?

3. What do preservice teachers identify as their knowledge needs on technology integration into teaching practice?

4. Are there statistically significant differences in preservice teachers' perceptions about the integration of technology and digital media by level of seniority in university studies and GPA? 


\section{Method}

A mixed methods approach was used in this research that integrates quantitative and qualitative data collection into this research. A mixed methods approach offers a powerful paradigm choice that can provide informative, complete, balanced, and useful research results (Johnson et al. 2007). A mixed methods approach can enable a deeper understanding of the problem under investigation by relating complementary findings from qualitative and quantitative research methods. A mixed approach can enhance the validity of the research results (Onwuegbuzie and Johnson 2006).

\section{Participants}

The participants were 192 preservice early childhood education teachers studying at the Hashemite University during the first semester of the academic year, 2018-2019. Participants all had the same area of specialization of early childhood education, and all were female.

Of the total sample, $19 \%$ had a GPA less than 2.5 (out of 4.00 ); $54 \%$ had a GPA that ranged from 2.5 to 2.99 ; and $27 \%$ a GPA that was 3.00 or higher. For seniority of study, 33\% of participants were sophomore (2nd year students), $45 \%$ were juniors (3rd year students), and 22\% were seniors (4th year students). The study did not include freshman (1st year students). The youngest participant was 20 years old, and the oldest was 29 years old; mean age was 21 years. The participants had already passed 33-100 credit hours in their studies in early childhood education and were also attending a compulsory computer education course. These students had already completed a number of courses that exposed them to technology-related topics.

\section{Research Instruments}

To elicit participants' perceptions on technology integration into early childhood education, a self-report questionnaire was prepared by the researchers. In its final version, the questionnaire contained 22 items in three domains: (a) perceptions of the importance of integrating technologies into early childhood education (8 items); 2) satisfaction with their current preparation for integrating technologies into early childhood teaching (7 items); and 3) current knowledge needs for integrating technology into early childhood teaching (7 items). In each domain of questions, respondents were asked to rate their agreement with each statement using a 5-point rating scale. The rating scale indicated: $1=$ strongly disagree; $2=$ disagree; $3=$ undecided; $4=$ agree; and 5= strongly agree.

The face and content validity of the questionnaire were reviewed by seven referees. The role of the referees was to confirm whether the content of the questionnaire was precise, appropriately worded, and adequate in order to elicit the required answers from the participants. Additionally, the questionnaire was field-tested with 12 preservice teachers outside of the study's sample. Changes needed that were 
identified by the referees, and field tests were addressed in the final development of the questionnaire. To estimate the reliability of the questionnaire, internal consistency measures were calculated using $\alpha$ Cronbach alpha for each domain in the questionnaire. The reliability analyses indicated that all questionnaire domains had high internal consistency: $\alpha=0.87$ (perceptions on the importance of technology integration), $\alpha=0.84$ (satisfaction with current preparation in technology integration), and $\alpha=0.84$ (current knowledge needs).

Additionally, in-depth interviews were also used to gain a deeper understating of participants' perceptions and provided in-depth and more detailed information (Minikel-Lacocque 2018). The interviews were conducted with the purpose of clarifying issues that were revealed after analyzing the data collected from the questionnaire. In total, 15 teachers were randomly selected for interview from those who had completed the questionnaire. To ensure the validity of the interview questions, the researchers distributed them to seven judges who provided feedback comments. Based on these comments, some of the interview questions were modified. A final version of the interview schedule included seven questions (see Appendix).

\section{Data Collection}

The researcher recruited two research assistants to distribute the questionnaires to the preservice teachers and to conduct the interviews. Participants received written instructions that specified the purpose of the study and explained the procedures to be followed when responding to the items. The questionnaire was administered to participants during the first semester of the academic year 2018/2019. The research assistants obtained participants' consent to participate in the study. Participants were ensured confidentiality and anonymity. They were asked to return the questionnaire to the class instructor who, in turn, returned it to the research assistants. Later, selected participants were interviewed. The interviews were conducted voluntarily in the students' room at the Deanship of Students' Affairs at the university. All interviews were recorded with the consent of the interviewees. Interviews were conducted in Arabic language, as most of the participants did not have an adequate knowledge of English. Each interview took approximately $15 \mathrm{~min}$. The researchers allowed the participants to withdraw from the interview at any time or to not answer any interview question, if they did not want to.

\section{Data Analysis}

Data were analyzed using the SPSS package version 20. Descriptive statistics, including mean and standard deviations, were generated to describe the preservice teachers' perceptions. One-way ANOVA was also utilized to determine any statistically significant differences among participants, with regard to seniority of study at university and GPA. The alpha level for significance was set at 0.05 a priori. All interviews were recorded and transcribed into a text file. Content analyses generated 
categories of responses for each question. Relevant quotes from the data were then identified to illustrate the categories identified (Lichtman 2012).

\section{Results}

Results from the analyses of the questionnaire focused on technology integration in early childhood teaching are reported, as well as qualitative excerpts from the in-depth interviews conducted on the same topic are reported in three sections that reflect the research questions: importance of technology integration in early childhood classrooms; satisfaction with preparation for technology integration; and knowledge needs that students identified for usage of technology and digital media in early childhood teaching. Differences in preservice teachers' responses by seniority in their teacher education course and GPA are also reported.

\section{Importance of Technology Integration in Early Childhood Classrooms}

The first research question examined preservice teachers' perceptions about the importance of integration of technology into early childhood education. Students were asked to respond to eight items, related to this topic. Descriptive statistics, including means and standard deviation for the items that addressed this topic, are shown in Table 1.

The overall mean score for these items was $4.2(\mathrm{SD}=0.62)$, indicating strongly positive perceptions of the importance of technology integration in early childhood education. Most of the items had high mean values above 4.0, on the 5-point scale. Items 1,5 , and 7 had the highest mean values (4.4, 4.3, and 4.3, respectively). Preservice early childhood teachers strongly believed that integrating technology into education is vital for children's learning and development, engages children in learning through audio-visual effects, and can be used to assess children's learning and development.

The interviews supported these findings obtained from the self-reported questionnaire. All interviewees noted the importance of technology and digital media in children's learning and development. They noted the benefits to young children. One participant stated:

It is obvious that technology improves the teaching and learning process. I, as a future teacher, should use technology in my classrooms, and all teachers should do the same. Children who live in our digital world should learn through technologies.

Another preservice teacher was eager to talk about this topic. She explained:

Technology and digital media are important tools that all teachers should use in the 21 st century. Technology motivates children to learn. When I become a teacher in the future, I will definitely use technology in my classroom. 


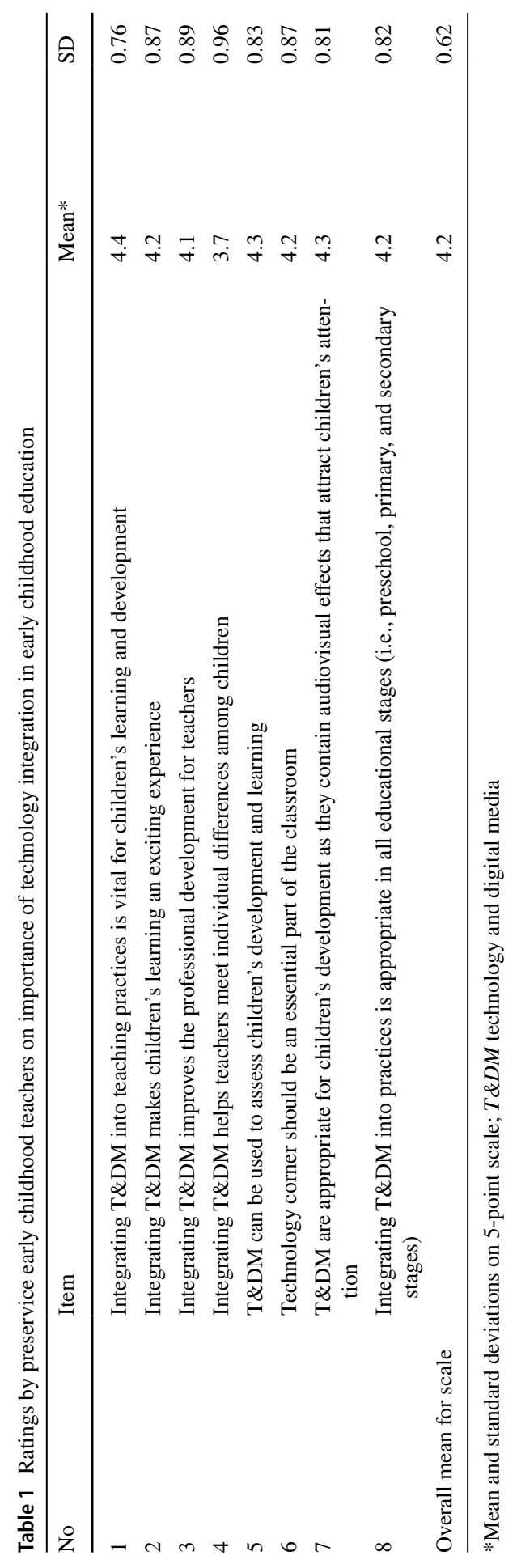




\section{Satisfaction with Preparation for Integrating Technology into Early Childhood Teaching}

The second research question examined preservice teachers' satisfaction with their preparation for technology integration. Descriptive statistics, including means and standard deviation for the seven items in the questionnaire that addressed this topic, are shown in Table 2.

Table 2 shows that preservice teachers' satisfaction with their preparation for technology integration into education ranged from low to moderate. Overall mean on this scale was $3.1(\mathrm{SD}=6.8)$. Items 1,2 , and 4 had the highest means on this scale and moderate mean values $(3.4,3.4$, and 3.4, respectively). Preservice teachers agreed that their courses focused more on practical aspects than on theoretical issues and encouraged them to integrate varied forms of technology. Item 3 had the lowest mean value (2.6) indicating that preservice teachers did not agree that their courses helped enhance their awareness and knowledge of how to integrate technology into education.

When interviewed, most preservice early childhood teachers (12 out 15) reported that they were dissatisfied with their preparation for technology integration into education. They indicated that the courses studied did not help them to integrate technology into education. Eight teachers mentioned that their technology courses, such as Using Computer in Teaching Children, dealt with theoretical aspects only and had nothing to do with technology integration. One of the teachers explained:

I did study technology-related courses. They were traditional and limited, to say the least. They focused on topics related to the importance of technology, its benefits to children, different scholars' views of technology...etc. They were useless. What I need is how to put these theories into practice, how to use technology in the classroom, and how to make children engage in technology.

Another teacher stated that:

Compared to the accelerating technological explosion in the 21 st century, I am not quite satisfied.

Most of the teachers interviewed (11 out of 15) indicated that integrating technology into education did not seem to be a priority in their study plan. They mentioned that technology-related courses were not adequate, as these courses neither improved their technological skills nor increased their awareness about how to integrate technology into education. Other preservice teachers argued that faculty members rarely used technology integration in their instructional practices. One preservice teacher stated:

We have, in our curriculum, one or two technology courses, and they will never prepare me for technology integration into education. The program should increase the number of courses we study and also develop their content. 


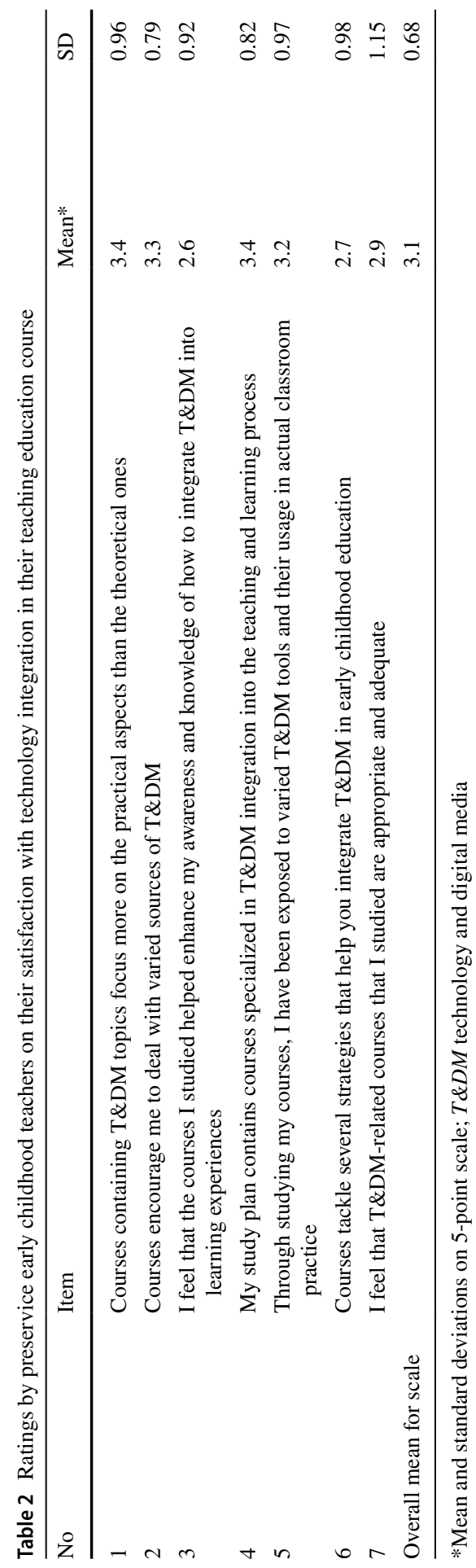


Table 3 Ratings by preservice early childhood teachers on their knowledge needs for learning to integrate technology into teaching practice

\begin{tabular}{|c|c|c|c|}
\hline No & Item & Mean* & SD \\
\hline \multicolumn{4}{|c|}{ I feel that I need to know more about... } \\
\hline 1 & Learning how to integrate $\mathrm{T} \& \mathrm{DM}$ into practice & 4.4 & 0.82 \\
\hline 2 & $\begin{array}{l}\text { Identifying the areas where T\&DM can be integrated into the child's } \\
\text { daily learning program }\end{array}$ & 4.1 & 0.95 \\
\hline 3 & Learning how to involve parents in children's T\&DM environment & 4.1 & 0.86 \\
\hline 4 & Learning how to integrate T\&DM in assessing children's development & 4.0 & 0.91 \\
\hline 5 & Learning how to make children engage in T\&DM activities & 4.2 & 0.90 \\
\hline 6 & $\begin{array}{l}\text { Designing T\&DM tools (i.e., educational programs, e-books, course- } \\
\text { ware... etc.) that facilitate children's learning and development }\end{array}$ & 4.2 & 0.89 \\
\hline 7 & Overcoming the obstacles that hinder integrating T\&DM in education & 4.1 & 0.93 \\
\hline \multicolumn{2}{|c|}{ Overall mean for scale } & 4.2 & 0.63 \\
\hline
\end{tabular}

*Mean and standard deviations on 5-point scale; $T \& D M$ technology and digital media

Another one stated:

I honestly lack technology skills. I, like many students, do not have an email account. Few courses employ the Model App and most of the students do not have access to this App or may not know how to use it.

Yet, another participant:

I feel that some instructors, who teach us at the college, do not believe that young children should be exposed to technology and digital media. Although they use smartphones and iPads in their daily lives, they do not use it in their classes, and this is big gap. I do believe that children should learn through technology; however, I do not know how to integrate technology into teaching in early years. This is disappointing as I am a senior student and this is my last year here at the university.

\section{Knowledge Needs About Technology Integration for Early Childhood Teaching}

Participants were asked to rate questionnaire items on their knowledge needs for learning how to integrate technology into classroom practice. Table 3 shows the means and standard deviations of teachers' responses to the questionnaires.

As shown in Table 3, the results indicated that early childhood teachers want to learn more about technology integration in education. The overall mean score for all seven items was $4.2(\mathrm{SD}=0.64)$. This indicates a high need to learn about technology integration. Items 1, 5, and 6 had the highest mean values (4.4, 4.2, and 4.2, respectively), as teachers felt that they needed to learn how to integrate technology 
in education, how to engage children in technology-based activities, and how to design technological tools to facilitate children's learning and development.

Interviewees felt that the information about, and implications for using technology which they were exposed to at the university were inadequate. They put forward a need for more courses related to technology integration in education. Two participants summed up this view by saying.

Yes... I need to know about how to integrate technology in early childhood education. I feel that what I studied at the university does not qualify me to use technology or to integrate it into the curriculum.

I thought the technology courses that I studied would allow me to acquire technological skills and that allow me to design technological tools and integrate them into classroom activities. Unfortunately, these courses concentrated on theoretical aspects. I really need to learn more in practical courses in technology.

However, a number of participants found that the technology-related courses offered by the university helped them to understand the importance of technology in education. They expressed the need to develop their knowledge and technological skills to facilitate children's technology use. As one preservice teacher explained:

We need to know about how to design technological tools and applications to facilitate children's learning. Children live in a world full of modern technologies. Thus, we need to acquire ways and means to take advantage of children's knowledge of technology to develop their learning.

\section{Seniority in Study and GPA: Differences in Responses}

The last research question explored the differences among the preservice teachers' perceptions of integrating technology into education according to: (1) seniority of study at university and (2) students GPA.

\section{Seniority of Study at University and Differences in Ratings Between Groups}

Student teachers were classified into three categories according to seniority of study at university (sophomore, junior, and senior). Freshman students were excluded from this study because they are not required to study technology-related courses in their first year at university. One-way ANOVA was used to examine differences among the three groups of preservice teachers' perceptions on importance of integrating technology into education, satisfaction with preparation for technology integration, and knowledge needs for learning about technology.

There was a significant difference between groups on the importance of integrating technology into early childhood teaching, $F(2.189)=23.569, p<0.000$. Post-hoc analyses using the Scheffé test was used to explore where differences lay between groups. Significant differences in the means were found between the seniors and the 
sophomore group (Mean difference $=0.699, p<0.000$ ); and between senior and the junior groups (Mean difference $=0.632, p<0.000$ ). From this result, it was apparent that seniors were most likely to rate the importance of technology integration more highly than sophomores and juniors.

There was a significant difference in preservice teachers' satisfaction with their preparation for integrating technology into practice, $F(2.189)=13.325, p<0.000$. Based on Scheffe's post-hoc tests, there were statistically significant differences between the seniors and the sophomore group, mean difference $=0.660, p<0.000$; and between the seniors and the juniors, mean difference $=0.417, p<0.003$. From these results, it seemed that seniors were more likely to rate their satisfaction with integration more highly than sophomores and juniors.

There was no significant difference in the levels of preservice teachers' knowledge needs with respect to technology integration. Therefore, post-hoc test for differences between groups was not necessary.

\section{Grade-Point Average (GPA) and Differences in Ratings Between Groups}

Participants in this study were classified into three categories according to their GPA (low, medium, and high). One-Way ANOVA was used to examine the differences among preservice teachers' perceptions of the importance of integrating technology into early childhood education, their satisfaction with their preparation for integrating technology, and their knowledge needs to learn about technology.

There were no statistically significant differences that could be attributed to students' GPA regarding their perceptions of the importance of integrating technology into early childhood education or their knowledge needs with respect to integration of technology. There was a statistically significant difference in preservice teachers' satisfaction with integrating technology into early childhood education, $F(2.189)=22.067, p=0.000$. The Scheffe's post-hoc test was used to explore the differences between groups. There was a significant difference between high GPA and low GPA groups in terms of satisfaction with technology integration, mean difference $=0.619, p=0.000$; as well as for high and low GPA groups, mean difference $=0.679, p=0.003$. From these results, it seemed that students with a high GPA were more likely to rate their satisfaction with integration more highly than the groups with low and medium GPA.

\section{Discussion}

Education researchers have emphasized the importance of integrating technology into classrooms to support children's learning (Donohue 2015; Ihmeideh and Alkhawaldeh 2017). Thus, technology needs to be integrated into teacher education programs (Tezci 2011; Tondeur et al. 2017). This present study examined the perceptions of preservice early childhood teachers with respect to the importance of integrating technology into classroom practice; their level of satisfaction with their preparation in using technology in teaching; and their knowledge needs about using 
technology in practice. In total, 192 student teachers completed the questionnaire, and 15 of these students were later interviewed.

\section{Review of Findings}

Results revealed that preservice early childhood teachers had positive perceptions on the importance of integrating technology into practice. A possible reason for this may be that they believe that technology has become part of our everyday lives and, therefore, should be integrated in classroom practice. Almost every part of our life is affected technology, and younger teachers have grown up with this technology (Bate 2010). Gao et al. (2011) also reported that these teachers may be more open to using technology in their own teaching practices in the future. Therefore, it is not surprising that preservice early childhood teachers valued the use of technology in facilitating children's learning (Govender and Govender 2009). These findings confirmed previous research about preservice early childhood teachers' views toward technology integration in their teaching practice and its importance in education (see Gulbahar 2008; Nikolopoulou and Gialamas 2009; Tezci 2011).

Despite the fact that the results of the self-reported questionnaire indicated that teachers' satisfaction with their preparation for technology and digital media integration was low to moderate, the interview results indicated more strongly that teachers were dissatisfied with their preparation. This finding is in line with Kay's (2006) work, which showed that preservice teachers did not feel adequately prepared to effectively integrate technology into their teaching practices. This is likely because the courses provided by the university were not adequately meeting the needs of the new generation of teachers. Furthermore, most courses taken by the student teachers may not have modeled good technology use (Tondeur et al. 2017).

Preservice teachers indicated in reporting on their knowledge needs wanted to learn more about different areas of technology. Teacher education programs should provide more focus on the development of student teachers' technological knowledge and skills by exposing them to stronger technology-related courses that help them transfer this knowledge and skills to actual teaching practices (Tondeur et al. 2013).

Preservice teachers' perceptions on the importance of integrating technology and digital media were dependent on their seniority of study at university. There was a statistically significant difference between their perceptions of importance and their seniority in study. Interestingly, the result of this study indicated that the seniors were not satisfied with their preparation at university. As most senior students studied practicum courses, it seems that the field experiences did not motivate them to integrate technology. In this respect, Tondeur et al. (2017) found that fieldwork experiences were the most significant factor influencing teachers' current teaching practices. With regard to student teachers' GPA, the results indicated that students with high GPAs were not sufficiently prepared to integrate technology. This is because their technology-related courses at university focused on more theoretical aspects. Although these student teachers may have passed these courses with high scores, they did not feel that the courses improved their technological knowledge 
and skills. Hu and McGrath (2011) also found that technology-integrated lessons were limited and traditional.

Concerning teachers' knowledge needs to learn more about technology integration in education, the results showed that there were no statistically significant differences among student teachers regardless of their seniority of study at university or their GPA. Their education program was not succeeding in meeting the technological needs of these student teachers.

\section{Conclusions and Implications}

While preservice teachers held positive perceptions of technology integration in education, they were not satisfied with their preparation for technology integration and wanted to learn more about technology integration into classroom practice. In light of these findings, we identify several implications for policy, practice, and research.

Early childhood teacher education programs should include policies and practices to ensure that preservice teachers acquire the necessary competencies for effective technology and digital media integration. Teacher education programs need to continue to expose preservice teachers to technology-related courses and give them opportunities to apply theoretical ideas about technology usage in innovative ways and evaluate the benefits of technology integration for children's learning. The results of this study highlighted a need for teacher education programs to review their curriculum plans and make sure that technology integration complements theoretical knowledge about such usage. Teacher education programs should be leaders in how best to integrate technology into fieldwork practice. Haydn and Barton (2007) argued that is a vital motivator for preservice teachers to demonstrate how technology can be used effectively in practice teaching.

During fieldwork, teacher education programs could pair preservice teachers with experienced cooperating teachers who have rich experiences in using technology with young children. Mueller et al. (2008) argued that experienced cooperating teachers are more likely to have the appropriate resources so that students can explore the educational value of technology in their teaching practice. Reshaping the curricula of teacher education programs is needed so that preservice teachers are better prepared for effective integration. At the international level, teacher education programs worldwide can change course offerings to recognize more strongly current advances in technology for use in education to support children's early learning and development.

Future research could address more strongly the challenges and benefits of technology integration, not only from the perspectives of preservice early childhood teachers, but also for other key players (i.e., university lecturers, cooperating teachers, parents, and children). Future research is also needed to examine the extent to which fieldwork influences technology integration by new teachers. The results of this present study could facilitate other international researchers to engage in comparative studies with a focus on different cultural perspectives on technology integration. As preservice early childhood teachers graduate from current courses, they 
need to be able to use innovative applications of technology and digital media into their teaching of young children.

\section{Appendix}

\section{Interview Schedule}

Q1: What do you think of integrating technology and digital media into kindergarten settings? Whether you are for or against technology integration, explain the reasons behind it.

Q2: In your opinion, what are the benefits to integrating technology and digital media into kindergarten classrooms for both the children and the teacher?

Q3: Do you think that what you have studied so far at the university will help you integrate technology into education when you become a teacher in the future? Please answer in detail.

Q4: Are you satisfied with what your university provides in terms of technology integration? Why, or why not?

Q5: Do you feel that you need to know more about technology integration and how it can be used in teaching children? In what areas do you feel that you need more information?

Q6: How would you rate your technological skills in the field of technology integration? Who contributed to the development of your skills?

Q7: Do you have any further comments regarding the use of technology in your setting, if so, please answer in detail.

\section{References}

Akbulut, Y. (2008). Exploration of the attitudes of freshman foreign language students toward using computers at a Turkish state university. The Turkish Online Journal of Educational Technology, $7(1), 1303-6521$.

Bate, F. (2010). A bridge too far? Explaining beginning teachers' use of ICT in Australian schools. Australasian Journal of Educational Technology, 26(7), 1042-1061.

Dong, C., \& Mertala, P. (2019). It is a tool, but not a 'must': early childhood preservice teachers' perceptions of ICT and its affordances. Early Years. https://doi.org/10.1080/09575146.2019.16272 93.

Donohue, C. (2015). Technology and digital media as tools for teaching and learning in the digital age. In C. Donohue (Ed.), Technology and digital media in the early years: Tools for teaching and learning (pp. 21-35). New York: NAEYC.

Gao, P., Wong, A. F., Choy, D., \& Wu, J. (2011). Beginning teachers' understanding performances of technology integration. Asia Pacific Journal of Education, 31(2), 211-223.

Govender, D., \& Govender, I. (2009). The relationship between information and communications technology (ICT) integration and teachers' self-efficacy beliefs about ICT. Education as Change, 13(1), 153-165. https://doi.org/10.1080/16823200902943346. 
Gulbahar, Y. (2008). Improving the technology integration skills of prospective teachers. Through practice: A case study. The Turkish Online Journal of Educational Technology, 7(4), 71-81.

Haydn, T., \& Barton, R. (2007). Common needs and different agendas: How trainee teachers make progress in their ability to use ICT in subject teaching. Some lessons from the UK. Computers and Education, 49(4), 1018-1036.

Hu, Z., \& McGrath, I. (2011). Innovation in higher education in China: Are teachers ready to integrate ICT in English language teaching? Technology Pedagogy and Education, 20(1), 41-59.

Ihmeideh, F. (2014). The effect of electronic books on enhancing emergent literacy skills of preschool children. Computers and Education, 79, 40-48.

Ihmeideh, F., Al-Basheer, A., \& Al-Momani, I. (2008). Jordanian student teachers' perceptions of teaching writing in kindergartens during their field training experience. European Journal of Teacher Education, 31(4), 403-417. https://doi.org/10.1080/02619760802420800.

Ihmeideh, F., \& Alkhawaldeh, M. (2017). Teachers' and parents' perceptions of the role of technology and digital media in developing child culture in the early years. Children and Youth Services Review, 77, 139-146.

Johnson, R., Onwuegbuzie, A., \& Turner, L. (2007). Toward a definition of mixed methods research. Journal of Mixed Methods Research, 1(2), 112-133.

Kay, R. (2006). Evaluating strategies used to incorporate technology into preservice education: A review of the literature. Journal of Research on Technology in Education, 38(4), 383-408.

Lichtman, M. (2012). Qualitative research in education: A user's guide (3rd ed.). New York: SAGE Publications, Inc.

Mahfouz, S., \& Ihmeideh, F. (2009). Attitudes of Jordanian university students towards using online chat discourse with native speakers of English for improving their language proficiency. Computer Assisted Language Learning, 22(3), 207-227.

Minikel-Lacocque, J. (2018). The affect-responsive interview and in-depth interviewing: What we can learn from therapy research. Qualitative Inquiry. https://doi.org/10.1177/1077800418792941.

Mueller, J., Wood, E., Willoughby, T., Ross, C., \& Specht, J. (2008). Identifying discriminating variables between teachers who fully integrate computers and teachers with limited integration. Computers and Education, 51(4), 1523-1537.

Nikolopoulou, K., \& Gialamas, V. (2009). Investigating preservice early childhood teachers' views and intentions about integrating and using computers in early childhood settings: compilation of an instrument. Technology Pedagogy and Education, 18(2), 201-219.

Onwuegbuzie, A., \& Johnson, R. (2006). The validity issue in mixed research. Research in the Schools, 13(1), 48-63.

Palaiologou, I. (2016). Children under five and digital technologies: implications for early years pedagogy. European Early Childhood Education Research Journal, 24(1), 5-24.

The Hashemite University. (2002). Field training instruction. Unpublished document: Queen Rania Institute for Childhood, Zarqa.

Tezci, E. (2011). Factors that influence preservice teachers' ICT usage in education. European Journal of Teacher Education, 34(4), 483-499.

Tang, T., \& Austin, M. (2009). Students' perceptions of teaching technologies, application of technologies, and academic performance. Computer and Education, 53(4), 1241-1255.

Tondeur, J., van Braak, J., Sang, G., Voogt, J., Fisser, P., \& Ottenbreit-Leftwich, A. (2012). Preparing preservice teachers to integrate technology in education: A synthesis of qualitative evidence. Computers and Education, 59(1), 134-144.

Tondeur, J., Pareja, R. N., van Braak, J., Fisser, P., \& Voogt, J. (2013). Technological pedagogical content knowledge in teacher education: In search of a new curriculum. Educational Studies, 39(2), 239-243.

Tondeur, J., Roblin, N., van Braak, J., Voogt, J., \& Prestridge, S. (2017). Preparing beginning teachers for technology integration in education: ready for take-off? Technology Pedagogy and Education, 26(2), 157-177. https://doi.org/10.1080/1475939X.2016.1193556.

Smahelova, M., Juhová, D., Cermak, I., \& Smahel, D. (2017). Mediation of young children's digital technology use: The parents' perspective. Cyberpsychology Journal of Psychosocial Research on Cyberspace. https://doi.org/10.5817/CP2017-3-4.

Yelland, N., Grieshaber, S., \& Stokes, J. (2006). Technology in Teacher Education: examples of integration and implementation in early childhood courses. Journal of Information Technology for Teacher Education, 9(1), 95-108. https://doi.org/10.1080/14759390000200080. 
Publisher's Note Springer Nature remains neutral with regard to jurisdictional claims in published maps and institutional affiliations. 